\title{
Idiomarina xiamenensis sp. nov., isolated from surface seawater, and proposal to transfer Pseudidiomarina aestuarii to the genus Idiomarina as Idiomarina aestuarii comb. nov.
}

\author{
Liping Wang,† Qiliang Lai,† Yuanyuan Fu, Hua Chen, Wanpeng Wang, \\ Jianning Wang, Fengqin Sun and Zongze Shao
}

Correspondence

Zongze Shao

shaozz@163.com
Key Laboratory of Marine Biogenetic Resources, Third Institute of Oceanography, State Oceanic Administration, Xiamen, PR China
A taxonomic study was carried out on strain $10-D-4^{\top}$, which was isolated from a crude oildegrading consortium enriched from surface seawater collected around Xiamen Island, PR China. Strain 10-D-4 $4^{\top}$ grew optimally at $\mathrm{pH} 7.0-8.0$ and at $25^{\circ} \mathrm{C}$. The $16 \mathrm{~S}$ rRNA gene sequence of strain $10-D-4^{\top}$ showed the highest similarity to those of Idiomarina salinarum ISL-52 ${ }^{\top}(94.6 \%)$, Idiomarina tainanensis $\mathrm{PIN}^{\top}{ }^{\top}(94.2 \%)$ and Idiomarina seosinensis CL-SP19 ${ }^{\top}(94.1 \%)$, and showed lower similarity (92.3-94.0\%) to other members of the genus Idiomarina. The major isoprenoid quinone was ubiquinone $8(\mathrm{Q}-8)$. The major fatty acids were iso- $\mathrm{C}_{13: 0}(5.2 \%)$, iso- $\mathrm{C}_{15: 0}(15.3 \%), \mathrm{C}_{16: 0}(14.3 \%)$, summed feature $3\left(\mathrm{C}_{16: 1} \omega 6 \mathrm{c}\right.$ and/or $\left.\mathrm{C}_{16: 1} \omega 7 \mathrm{c}\right)(6.6 \%)$, iso- $\mathrm{C}_{17: 0}(15.4 \%)$ and $\mathrm{C}_{18: 1} \omega 7 c(13.5 \%)$. The $\mathrm{G}+\mathrm{C}$ content of the chromosomal DNA was $50.4 \mathrm{~mol} \%$. Phylogenetic analysis based on 16S rRNA gene sequences, together with data from phenotypic and chemotaxonomic characterization, revealed that strain $10-D-4^{\top}$ represents a novel species of the genus Idiomarina, for which the name Idiomarina xiamenensis sp. nov. is proposed. The type strain is $10-\mathrm{D}-4^{\top}$ (=CCTCC AB $209061^{\top}=\mathrm{LMG} 25227^{\top}=$ MCCC $1 \mathrm{A01370}{ }^{\top}$ ). We also propose the transfer of Pseudidiomarina aestuarii, described recently, to the genus Idiomarina as Idiomarina aestuarii comb. nov. (type strain $\mathrm{KYW} 14^{\top}=\mathrm{KCTC} 22740^{\top}=\mathrm{JCM}$ $\left.16344^{\top}\right)$.
In an attempt to investigate crude oil-degrading bacteria from surface seawater around Xiamen Island, PR China, several bacterial strains were isolated and characterized taxonomically. This study focused on one of these isolates, designated strain $10-\mathrm{D}-4^{\mathrm{T}}$. 16S rRNA gene sequence analysis indicated that strain $10-\mathrm{D}-4^{\mathrm{T}}$ formed a clade within the genus Pseudidiomarina (Idiomarina). The genus Idiomarina was first proposed by Ivanova et al. (2000), while the genus Pseudidiomarina was established later, by Jean et al. (2006). Both genera belong to the family Idiomarinaceae and, at the time of writing, nine species of Idiomarina and seven species of Pseudidiomarina had been described. However, it is not possible to distinguish the genera from each other by using the phenotypic or chemotaxonomic characteristics examined, except for differences in $16 \mathrm{~S}$ rRNA gene sequence signature nucleotides, and Taborda et al. (2009) proposed

†These authors contributed equally to this work.

The GenBank/EMBL/DDBJ accession number for the 16S rRNA gene sequence of strain 10-D-4 $4^{\top}$ is GU471247.

A supplementary figure and a supplementary table are available with the online version of this paper. the transfer of the species classified in the genus Pseudidiomarina to the genus Idiomarina. Hence, the genus Idiomarina contained 16 species with validly published names. Since this proposal, another species, Pseudidiomarina aestuarii, has been described (Park et al., 2010), which should also be transferred to the genus Idiomarina based on $16 \mathrm{~S}$ rRNA gene sequence phylogeny and phenotypic properties, as proposed by Taborda et al. (2009). The aim of the present work was to determine the exact taxonomic position of strain $10-\mathrm{D}-4^{\mathrm{T}}$ by using a polyphasic method that included determination of phenotypic properties and a detailed phylogenetic analysis based on 16S rRNA gene sequences.

Surface seawater was sampled around Xiamen Island $\left(24^{\circ}\right.$ $28^{\prime} \mathrm{N} 118^{\circ} 11^{\prime} \mathrm{E}$ ) in October 2005. Once collected, $150 \mathrm{ml}$ seawater was subsampled into sterilized bottles. To start the enrichment, the seawater was supplemented with $1 \mathrm{ml}$ sterilized crude oil (as a carbon source) and nitrogen, phosphorus and iron sources with concentrations as in $\mathrm{NH}$ medium (Wang et al., 2010). Cultures were incubated at $25{ }^{\circ} \mathrm{C}$ with shaking (150 r.p.m.) for 10 days. Serial dilutions of enrichments were streaked on HLB agar plates (Liu \& Shao, 2005) and incubated at $25{ }^{\circ} \mathrm{C}$. Representative 
colonies were picked and restreaked onto HLB plates to obtain pure cultures. For morphological and biochemical characterization, strain $10-\mathrm{D}-4^{\mathrm{T}}$ was cultivated on marine agar 2216 (MA; BD Difco).

Genomic DNA was prepared according to the method of Ausubel et al. (1995) and the 16S rRNA gene was amplified by PCR using primers described previously (Liu \& Shao, 2005). Identification of phylogenetic neighbours and calculation of pairwise 16S rRNA gene sequence similarities were achieved using the EzTaxon server (http://www. eztaxon.org/; Chun et al., 2007). Sequences of related taxa were obtained from the GenBank database. Phylogenetic analysis was performed using MEGA version 4 (Tamura et al., 2007) after multiple alignment of data by DNAMAN (version 5.1; Lynnon Biosoft). Distances (distance options according to Kimura's two-parameter model) and clustering with the neighbour-joining (Saitou \& Nei, 1987) and minimum-evolution (Rzhetsky \& Nei, 1992, 1993) methods were determined by using bootstrap values based on 1000 replications. As the result of the minimum-evolution analysis was similar to that obtained with the neighbourjoining method, the results are not shown.

A nearly full-length $16 \mathrm{~S}$ rRNA gene sequence (1504 nt) of strain $10-\mathrm{D}-4^{\mathrm{T}}$ was obtained. Phylogenetic analysis indicated that strain $10-\mathrm{D}-4^{\mathrm{T}}$ belonged to the family Idiomarinaceae, forming a robust clade with members of the genus Idiomarina (Fig. 1). The closest related strain was Idiomarina salinarum ISL- $52^{\mathrm{T}}$ (94.6\% similarity), followed by I. tainanensis PIN1 ${ }^{\mathrm{T}}(94.2 \%)$ and I. seosinensis CL-SP19 ${ }^{\mathrm{T}}$ (94.1\%), and lower similarities (92.3-94.0\%) were shown to other members of the genus Idiomarina. In general, $16 \mathrm{~S}$ rRNA gene sequence divergence greater than $3 \%$ is accepted as a criterion for delineating different species (Stackebrandt \& Goebel, 1994). The 16S rRNA gene sequence divergence between strain $10-\mathrm{D}-4^{\mathrm{T}}$ and recognized species was $>5.4 \%$, and the data therefore support the view that strain $10-\mathrm{D}-4^{\mathrm{T}}$ represents a novel species. In addition, [Pseudidiomarina] aestuarii KYW $314^{\mathrm{T}}$ showed highest similarity $(97.3 \%)$ with I. salinarum ISL-52 ${ }^{\mathrm{T}}$, and shared $93.7-96.7 \%$ sequence identity with other Idiomarina species. As the species of the genus Pseudidiomarina were transferred to the genus Idiomarina by Taborda et al. (2009), [Pseudidiomarina] aestuarii should also be transferred to the genus Idiomarina. Differential characteristics and DNA-DNA hybridization results between [Pseudidiomarina] aestuarii $\mathrm{KYW} 314^{\mathrm{T}}$ and the closest type strains, I. salinarum ISL-52 ${ }^{\mathrm{T}}$ and Idiomarina taiwanensis PIT1 ${ }^{\mathrm{T}}$, were shown by Park et al. (2010). As shown in Table 1, [Pseudidiomarina] aestuarii KYW $314^{\mathrm{T}}$ possesses the specific signature nucleotides of rRNA group 2 except for position 143. However, strain $10-\mathrm{D}-4^{\mathrm{T}}$ could not be assigned to either rRNA group, as half of the specific signature nucleotides differ from those of both rRNA groups, and we propose that it represents rRNA group 3 of the genus Idiomarina.

The Gram reaction, catalase, oxidase and lipase (Tween 80 ) activities, hydrolysis of aesculin and starch, optimal growth temperature and $\mathrm{pH}$, tolerance of $\mathrm{NaCl}$, antibiotic susceptibility and general cell morphology by electron microscopy were studied as described previously (Lai et al., 2009). $\mathrm{H}_{2} \mathrm{~S}$ production was assessed according to Dong \& Cai (2001). Other biochemical tests were carried out using API 20NE and API ZYM strips (bioMérieux) according to the manufacturer's instructions, except that the $\mathrm{NaCl}$ concentration was adjusted to $3.0 \%$ in all tests. I. salinarum KCTC $12971^{\mathrm{T}}$ and I. tainanensis $\mathrm{PIN1}^{\mathrm{T}}$ were tested at the same time for comparison. These results are given in the species description and Table 2.

Analysis of the respiratory quinones of strain $10-\mathrm{D}-4^{\mathrm{T}}$ was carried out by the Identification Service of the DSMZ and Dr Brian Tindall (Braunschweig, Germany). The major quinone was ubiquinone 8 (Q-8; $97 \%)$, in agreement with all members of the genus Idiomarina. Minor amounts of Q-7 (3\%) were also present. Fatty acids in whole cells grown on MA at $28{ }^{\circ} \mathrm{C}$ for $48 \mathrm{~h}$ were extracted, saponified

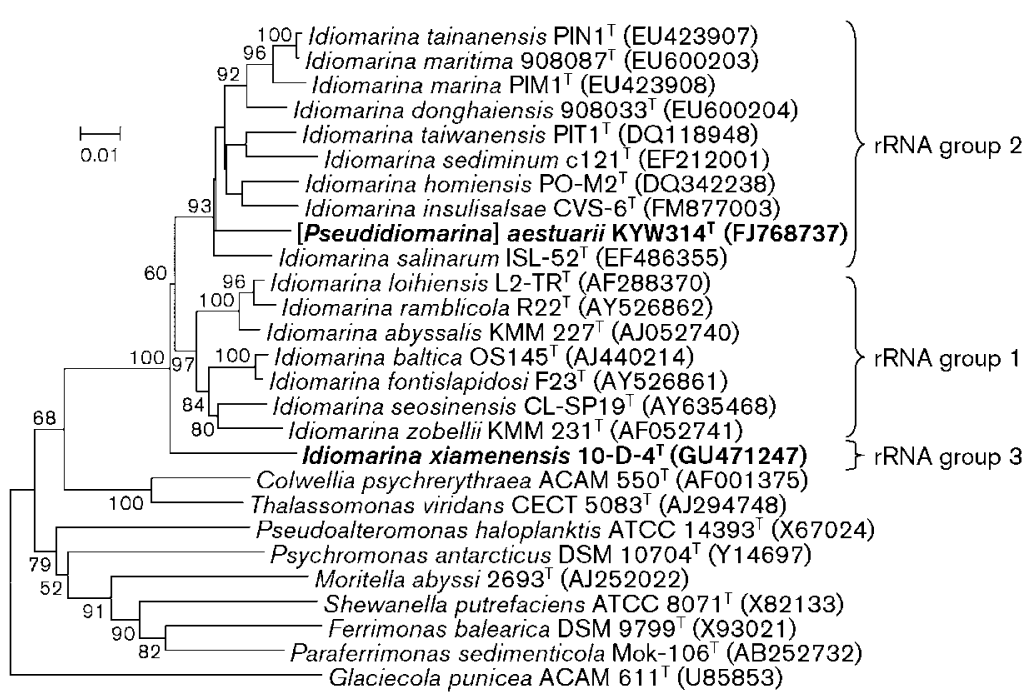

Fig. 1. Neighbour-joining tree showing the phylogenetic positions of strain $10-\mathrm{D}-4^{\top}$ and representatives of some other related taxa, based on 16S rRNA gene sequences. Bootstrap values (expressed as percentages of 1000 replications) are shown at branch points. Bar, 0.01 substitution rate $\left(K_{\text {nuc }}\right)$ units. 
Table 1. $16 \mathrm{~S}$ rRNA gene sequence signature sites detected among strain $10-\mathrm{D}-4^{\top}$ and two groups found in the family Idiomarinaceae cluster

Signature sites for the family Idiomarinaceae are shown in bold; other entries indicate signature sites for each rRNA group. rRNA groups are numbered according to Taborda et al. (2009).

\begin{tabular}{|c|c|c|c|c|c|c|c|c|c|c|c|c|c|}
\hline \multirow[t]{2}{*}{ Group/strain } & \multicolumn{13}{|c|}{ Position } \\
\hline & 143 & 206 & 213 & 241 & 285 & 653 & 662 & 658 & 682 & 748 & 830 & 856 & 1256 \\
\hline rRNA group 2 & A & $\mathrm{U}$ & A & A & $\mathrm{U}$ & $\mathrm{C}$ & A & $\mathrm{U}$ & $A(U)$ & A & $\mathbf{U}$ & A & A \\
\hline Strain $10-\mathrm{D}-4^{\mathrm{T}}$ & $\mathrm{T}$ & $\mathrm{U}$ & A & A & $\mathrm{U}$ & A & G & $\mathrm{C}$ & $\mathbf{A}$ & G & $\mathbf{U}$ & A & $\mathrm{C}$ \\
\hline$[P$.$] aestuarii KYW 314^{\mathrm{T}}$ & $\mathbf{T}$ & $\mathrm{U}$ & A & A & $\mathrm{U}$ & $\mathrm{C}$ & A & $\mathrm{U}$ & A & A & $\mathbf{U}$ & A & A \\
\hline
\end{tabular}

and esterified; this was followed by GC analysis of the fatty acid methyl esters according to the instructions of the MIDI system (Sasser, 1997). I. salinarum KCTC $12971^{\mathrm{T}}$ and I. tainanensis $\mathrm{PIN}^{\mathrm{T}}$ were analysed in parallel with strain $10-\mathrm{D}-4^{\mathrm{T}}$ in this study. As shown in Supplementary Table S1 (available in IJSEM Online), the major fatty acids of strain $10-\mathrm{D}-4^{\mathrm{T}}$ were iso- $\mathrm{C}_{13: 0}(5.2 \%)$, iso- $\mathrm{C}_{15: 0}$ $(15.3 \%), \mathrm{C}_{16: 0}(14.3 \%)$, summed feature $3\left(\mathrm{C}_{16: 1} \omega 6 \mathrm{c}\right.$

Table 2. Characteristics of strain $10-\mathrm{D}-4^{\top}$ and type strains of related /diomarina species

Strains: 1, 10-D-4 ${ }^{\mathrm{T}} ; 2$, I. salinarum ISL-52 ${ }^{\mathrm{T}}$ (unless indicated, data from Yoon et al., 2007); 3, I. tainanensis PIN1 ${ }^{\mathrm{T}}$ (unless indicated, data from Jean et al., 2009); 4, [P.] aestuarii KYW314 ${ }^{\mathrm{T}}$ (Park et al., 2010). Data on catalase and oxidase activities, API 20NE and API ZYM tests, tolerance of NaCl and antibiotic susceptibility were obtained in parallel for I. salinarum KCTC $12971^{\mathrm{T}}$ and I. tainanensis PIN ${ }^{\mathrm{T}}$ in this study. In API $20 \mathrm{NE}$ tests, all strains were positive for gelatin hydrolysis and negative for indole production, D-glucose fermentation, $\beta$-glucosidase and $\beta$-galactosidase activities and utilization of all 12 carbon sources. In API ZYM tests, all strains were positive for alkaline phosphatase and $\alpha$-chymotrypsin and negative for $N$ acetyl- $\beta$-glucosaminidase, $\alpha$-fucosidase, $\alpha$-galactosidase, $\alpha$-glucosidase, $\alpha$-mannosidase, $\beta$-galactosidase, $\beta$-glucosidase and $\beta$-glucuronidase. + , Positive; $\mathrm{w}$, weakly positive; -, negative; ND, no data available.

\begin{tabular}{|c|c|c|c|c|}
\hline Characteristic & 1 & 2 & 3 & 4 \\
\hline Cell width $(\mu \mathrm{m})$ & $0.4-0.6$ & $0.3-0.6$ & $0.6-0.9$ & 0.3 \\
\hline Cell length $(\mu \mathrm{m})$ & $1.2-1.7$ & $0.8-3.5$ & $2.5-3.2$ & $0.7-1.4$ \\
\hline Catalase & $\mathrm{w}$ & + & + & + \\
\hline $\mathrm{NaCl}$ range $(\%, \mathrm{w} / \mathrm{v})$ & $0-15$ & $1-14$ & $0.5-15$ & $1-10$ \\
\hline $\mathrm{NaCl}$ optimum $(\%, w / v)$ & $1-3$ & $2-3$ & $2-5$ & 3 \\
\hline Temperature optimum $\left({ }^{\circ} \mathrm{C}\right)$ & 25 & $30-37$ & $30-35$ & 30 \\
\hline Nitrate reduction & - & + & - & - \\
\hline Arginine dihydrolase & + & - & - & - \\
\hline Urease & + & - & + & - \\
\hline \multicolumn{5}{|l|}{ Hydrolysis of: } \\
\hline Aesculin & + & - & - & + \\
\hline Cystine aminopeptidase, trypsin & $\mathrm{w}$ & + & + & - \\
\hline Esterase (C4) & + & $\mathrm{w}$ & $\mathrm{w}$ & - \\
\hline Lipase (C14), valine aminopeptidase & + & $\mathrm{w}$ & + & - \\
\hline \multicolumn{5}{|l|}{ Susceptibility to: } \\
\hline Cefobid, cephradin, gentamicin, minomycin & - & - & + & $\mathrm{ND}$ \\
\hline Co-trimoxazole & - & + & + & $\mathrm{ND}$ \\
\hline Vancomycin & - & + & + & - \\
\hline Norfloxacin, ofloxacin & + & - & + & $\mathrm{ND}$ \\
\hline Penicillin G & - & - & + & + \\
\hline DNA G $+C$ content $(\mathrm{mol} \%)$ & 50.4 & 53.9 & 46.9 & 56.4 \\
\hline
\end{tabular}


and/or $\left.\mathrm{C}_{16: 1} \omega 7 c\right)(6.6 \%)$, iso- $\mathrm{C}_{17: 0}(15.4 \%)$ and $\mathrm{C}_{18: 1} \omega 7 c$ $(13.5 \%)$. This profile was similar to those of other members of the genus Idiomarina. However, strain 10-D$4^{\mathrm{T}}$ can be differentiated from its closest relative I. salinarum KCTC $12971^{\mathrm{T}}$ by the amounts of $\mathrm{C}_{16: 0}(14.3$ vs $7.8 \%)$, summed feature $8\left(\mathrm{C}_{18: 1} \omega 7 c\right.$ and/or $\left.\mathrm{C}_{18: 1} \omega 6 c\right)$ (13.5 vs $6.2 \%), \mathrm{C}_{19: 0}$ cyclo $\omega 8 c(4.0$ vs $0 \%)$ and summed feature 9 (iso- $\mathrm{C}_{17: 1} \omega 9 \mathrm{c}$ and/or 10 -methyl $\mathrm{C}_{16: 0}$ ) (6.7 vs $23.5 \%$ ). The proportions of most fatty acids in strain $10-\mathrm{D}-4^{\mathrm{T}}$ were within the ranges reported by Taborda et al. (2009) (Supplementary Table S1).

The $\mathrm{G}+\mathrm{C}$ content of the chromosomal DNA was determined according to the method described by Mesbah \& Whitman (1989) by reversed-phase HPLC analysis. The DNA G $+\mathrm{C}$ content of strain $10-\mathrm{D}-4^{\mathrm{T}}$ was $50.4 \mathrm{~mol} \%$, within the range of values reported for known Idiomarina species (45.0-56.4 mol\%).

Phylogenetic analysis based on 16S rRNA gene sequences, physiological features, respiratory quinone and fatty acid profiles suggest that strain $10-\mathrm{D}-4^{\mathrm{T}}$ belongs to the genus Idiomarina and represents a novel species of this genus. Physiological features that differentiate strain $10-\mathrm{D}-4^{\mathrm{T}}$ from I. salinarum KCTC $12971^{\mathrm{T}}$ include differences in nitrate reduction, arginine dihydrolase, urease and hydrolysis of aesculin and Tween 80. The name Idiomarina xiamenensis sp. nov. is proposed. It is also proposed that Pseudidiomarina aestuarii Park et al. 2010 is reclassified as Idiomarina aestuarii comb. nov.

\section{Description of Idiomarina xiamenensis sp. nov.}

Idiomarina xiamenensis (xia.me.nen'sis. N.L. fem. adj. xiamenensis of Xiamen, a city in Fujian, PR China, where the type strain was isolated).

Cells are rod-shaped, $1.2-1.7 \mu \mathrm{m}$ long and $0.4-0.6 \mu \mathrm{m}$ wide, motile by one polar flagellum (Supplementary Fig. S1). Positive for oxidase, catalase (weak), urease, $\beta$ glucosidase (aesculin hydrolysis), gelatinase and arginine dihydrolase, but negative for Gram reaction, amylase, indole production, lipase (Tween 80 ), $\beta$-galactosidase, $\mathrm{H}_{2} \mathrm{~S}$ production and reduction of nitrate to nitrite. On MA, forms smooth, grey colonies with regular edges, $1-2 \mathrm{~mm}$ in diameter after $72 \mathrm{~h}$ of incubation at $28{ }^{\circ} \mathrm{C}$. Grows in 0 $15 \% \mathrm{NaCl}$ (optimum $1-3 \%$ ), at $4-42{ }^{\circ} \mathrm{C}$ (optimum $25{ }^{\circ} \mathrm{C}$ ) and at $\mathrm{pH}$ 6-10 (optimum $\mathrm{pH} 7-8$ ). Unable to ferment glucose. The major isoprenoid quinone is ubiquinone 8 (Q-8). Principal fatty acids are iso- $\mathrm{C}_{13: 0}$, iso- $\mathrm{C}_{15: 0}, \mathrm{C}_{16: 0}$, summed feature $3\left(\mathrm{C}_{16: 1} \omega 6 \mathrm{c}\right.$ and/or $\left.\mathrm{C}_{16: 1} \omega 7 c\right)$, iso- $\mathrm{C}_{17: 0}$ and $\mathrm{C}_{18: 1} \omega 7 c$. Sensitive to ( $\mu \mathrm{g}$ per disc unless indicated; Oxoid) ampicillin (10), carbenicillin (100), cefazolin (30), chloromycetin (30), ciprofloxacin (5), erythromycin (15), kanamycin (30), norfloxacin (10), ofloxacin (5), polymyxin B (30 IU), rifampicin (5) and rocephin (30); resistant to cefalexin (30), cefobid (30), cephradin (30), clindamycin (2), co-trimoxazole (25), furazolidone (15), gentamicin (10), lincomycin (2g), metronidazole (5), minomycin (30), neomycin (10), oxacillin (1), penicillin $G(10)$, piperacillin
(100), streptomycin (10), tetracycline (30), vancomycin (30) and vibramycin (30). In API ZYM tests, positive for acid phosphatase, alkaline phosphatase, cystine aminopeptidase, esterase (C4), esterase lipase (C8), leucine aminopeptidase, lipase (C14) (weak), naphthol-AS-BI-phosphoamidase, trypsin (weak), valine aminopeptidase and $\alpha$-chymotrypsin; negative for $N$-acetyl- $\beta$-glucosaminidase, $\alpha$-fucosidase, $\alpha$ galactosidase, $\alpha$-glucosidase, $\alpha$-mannosidase, $\beta$-galactosidase, $\beta$-glucosidase and $\beta$-glucuronidase. Cannot utilize any of the 12 carbon sources included in the API 20NE strip. The DNA G + C content of the type strain is $50.4 \mathrm{~mol} \%$. Table 1 shows characteristics that can be used to distinguish the species from related species.

The type strain, $10-\mathrm{D}-4^{\mathrm{T}}$ (=CCTCC AB $209061^{\mathrm{T}}=\mathrm{LMG}$ $25227^{\mathrm{T}}=$ MCCC $1 \mathrm{~A} 01370^{\mathrm{T}}$ ), was isolated from surface seawater around Xiamen Island, PR China.

\section{Description of Idiomarina aestuarii comb. nov.}

Idiomarina aestuarii (aes.tu.a'ri.i. L. gen. n. aestuarii of the shallow coast, from where the type strain was isolated).

Basonym: Pseudidiomarina aestuarii Park et al. 2010.

The description is identical to that given for Pseudidiomarina aestuarii by Park et al. (2010). The type strain is KYW314 ${ }^{\mathrm{T}}$ $\left(=\right.$ KCTC $\left.22740^{\mathrm{T}}=\mathrm{JCM} 16344^{\mathrm{T}}\right)$, isolated from seawater collected from the South Sea, Republic of Korea.

\section{Acknowledgements}

This work was supported financially by the Youth Marine Science Foundation of the State Oceanic Administration, China (grant no. 2011149), the National Infrastructure of Natural Resources for Science and Technology Program of China (no. 2005DKA21209) and the Natural Science Foundation of Fujian Province of China (no. 2009J01177). We thank Dr Wung Yang Shieh for kindly providing the type strain I. tainanensis $\mathrm{PIN}^{\mathrm{T}}$.

\section{References}

Ausubel, F. M., Brent, R., Kingston, R. E., Moore, D. D., Seidman, J. G., Smith, J. A. \& Struhl, K. (editors) (1995). Short Protocols in Molecular Biology: a Compendium of Methods from Current Protocols in Molecular Biology, 3rd edn. New York: Wiley.

Chun, J., Lee, J.-H., Jung, Y., Kim, M., Kim, S., Kim, B. K. \& Lim, Y. W. (2007). EzTaxon: a web-based tool for the identification of prokaryotes based on $16 \mathrm{~S}$ ribosomal RNA gene sequences. Int J Syst Evol Microbiol 57, 2259-2261.

Dong, X.-Z. \& Cai, M.-Y. (2001). Determinative Manual for Routine Bacteriology. Beijing: Scientific Press.

Ivanova, E. P., Romanenko, L. A., Chun, J., Matte, M. H., Matte, G. R., Mikhailov, V. V., Svetashev, V. I., Huq, A., Maugel, T. \& Colwell, R. R. (2000). Idiomarina gen. nov., comprising novel indigenous deep-sea bacteria from the Pacific Ocean, including descriptions of two species, Idiomarina abyssalis sp. nov. and Idiomarina zobellii sp. nov. Int J Syst Evol Microbiol 50, 901-907.

Jean, W. D., Shieh, W. Y. \& Chiu, H. H. (2006). Pseudidiomarina taiwanensis gen. nov., sp. nov., a marine bacterium isolated from shallow coastal water of An-Ping Harbour, Taiwan, and emended 
description of the family Idiomarinaceae. Int J Syst Evol Microbiol 56, 899-905.

Jean, W. D., Leu, T. Y., Lee, C.-Y., Chu, T. J., Lin, S. Y. \& Shieh, W. Y. (2009). Pseudidiomarina marina sp. nov. and Pseudidiomarina tainanensis sp. nov. and reclassification of Idiomarina homiensis and Idiomarina salinarum as Pseudidiomarina homiensis comb. nov. and Pseudidiomarina salinarum comb. nov., respectively. Int J Syst Evol Microbiol 59, 53-59.

Lai, Q., Yuan, J., Gu, L. \& Shao, Z. (2009). Marispirillum indicum gen. nov., sp. nov., isolated from a deep-sea environment. Int J Syst Evol Microbiol 59, 1278-1281.

Liu, C. \& Shao, Z. (2005). Alcanivorax dieselolei sp. nov., a novel alkanedegrading bacterium isolated from sea water and deep-sea sediment. Int J Syst Evol Microbiol 55, 1181-1186.

Mesbah, M. \& Whitman, W. B. (1989). Measurement of deoxyguanosine/thymidine ratios in complex mixtures by high-performance liquid chromatography for determination of the mole percentage guanine + cytosine of DNA. J Chromatogr A 479, 297-306.

Park, S., Lim, C., Baik, K., Lee, K., Lee, J. \& Seong, C. (2010). Pseudidiomarina aestuarii sp. nov., a marine bacterium isolated from shallow coastal seawater. Int J Syst Evol Microbiol 60, 2071-2075.

Rzhetsky, A. \& Nei, M. (1992). A simple method for estimating and testing minimum evolution trees. Mol Biol Evol 9, 945-967.

Rzhetsky, A. \& Nei, M. (1993). Theoretical foundation of the minimum-evolution method of phylogenetic inference. Mol Biol Evol 10, 1073-1095.
Saitou, N. \& Nei, M. (1987). The neighbor-joining method: a new method for reconstructing phylogenetic trees. Mol Biol Evol 4, 406425.

Sasser, M. (1997). Identification of bacteria by gas chromatography of cellular fatty acids. MIDI Technical Note 101. Newark, DE: MIDI.

Stackebrandt, E. \& Goebel, B. M. (1994). Taxonomic note: a place for DNA-DNA reassociation and 16S rRNA sequence analysis in the present species definition in bacteriology. Int J Syst Bacteriol 44, 846849.

Taborda, M., Antunes, A., Tiago, I., Veríssimo, A., Nobre, M. F. \& da Costa, M. S. (2009). Description of Idiomarina insulisalsae sp. nov., isolated from the soil of a sea salt evaporation pond, proposal to transfer the species of the genus Pseudidiomarina to the genus Idiomarina and emended description of the genus Idiomarina. Syst Appl Microbiol 32, 371-378.

Tamura, K., Dudley, J., Nei, M. \& Kumar, S. (2007). MEGA4: molecular evolutionary genetics analysis (MEGA) software version 4.0. Mol Biol Evol 24, 1596-1599.

Wang, L., Wang, W., Lai, Q. \& Shao, Z. (2010). Gene diversity of CYP153A and AlkB alkane hydroxylases in oil-degrading bacteria isolated from the Atlantic Ocean. Environ Microbiol 12, 12301242.

Yoon, J. H., Jung, S. Y., Jung, Y. T. \& Oh, T. K. (2007). Idiomarina salinarum sp. nov., isolated from a marine solar saltern in Korea. Int $J$ Syst Evol Microbiol 57, 2503-2506. 